\author{
Нікішина О.В. \\ доктор економічних наук, старший науковий співробітник \\ завідувач відділу ринкових механізмів та структур \\ Інститут проблем ринку та економіко-екологічних досліджень НАН України \\ Французький бульвар, 29, м. Одеса, Україна, 65044 \\ E-mail: ksenkych@gmail.com \\ ORCID ID: 0000-0002-7172-3551
}

\title{
СЦЕНАРІЇ ТА СТРАТЕГІЧНІ НАПРЯМИ ІННОВАЦІЙНОГО РОЗВИТКУ РЕГІОНАЛЬНОГО РИНКУ ЗЕРНА Й ПРОДУКТІВ ЙОГО ПЕРЕРОБКИ НА ЗАСАДАХ ГЛОКАЛІЗАЦІї *
}

\begin{abstract}
У статті обґрунтовано методологічні аспекти глокалізації товарних ринків, акцентовано увагу на цільовий орієнтир даного процесу - забезпечення ефективної інтеграції локальних ринків до глобального простору на засадах реалізації економічних інтересів регіону / держави. Визначено головні проблеми інноваційного розвитку стратегічного ринку зерна та продуктів його переробки в Одеській області, економічні інтереси регіону на даному ринку. Окреслено сценарії інноваційного розвитку досліджуваного ринку, які відображають зв'язок між ступенем реалізації економічних інтересів регіону / держави та ступенем глокалізації товарного ринку. Зазначено, що в Одеській області та державі в цілому ринкова глокалізація носить сировинний характер, що не відповідає ії економічним інтересам та не сприяє впровадженню інновацій в зерновій сфрері та розвитку локальних територій. На підставі емпіричних досліджень обґрунтовано стратегічні напрями й інструменти інноваційного розвитку регіонального ринку зерна та продуктів його переробки на засадах глокалізації.
\end{abstract}

Ключові слова: глокалізація, товарний ринок, інноваційний розвиток, ринок зерна та продуктів його переробки, економічні інтереси регіону.

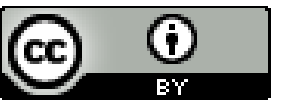

This work is licensed under a Creative Commons Attribution 4.0 International License http://creativecommons.org/licenses/by/4.0/

Постановка проблеми та її зв'язок з важливими науковими та практичними завданнями. В умовах глобалізації та зовнішньоекономічної інтеграції товарних ринків активізуються процеси їх глокалізації. Особливістю сучасного процесу глокалізації $€$ виведення локальних територій (регіонів) безпосередньо у глобальний світ (так звана «глобалізація знизу»), зростання кількості й тісноти зв'язків із суміжними територіями (активізація транскордонного співробітництва), розвиток міжрегіональних об’єднань (єврорегіонів) [1, с. 200]. У ринковому вимірі процес глокалізації залишається недостатньо дослідженим. Даний процес набуває нових властивостей і тенденцій у залежності від специфіки відтворення ресурсів у певному товарному ринку, його типу, секторної структури, ступеню впливу держави та різних інституцій, розвиненості інституційного середовища тощо.

Під глокалізаиією товарного ринку ми розуміємо процес розширення товарних, територіальних і часових меж локального ринку за рахунок організації його суб'єктами виробництва й експорту інновацій- них видів товарів і послуг із новими споживчими якостями, освоєння інноваційних процесів і методів управління, формування зовнішніх партнерських зв'язків і взаємодій із забезпеченням економічних інтересів регіону / держави [2]. Початковим етапом глокалізації $\epsilon$ розширення товарних меж ринку за рахунок появи в регіоні виробництв інноваційних видів товарів і послуг із новими споживчими якостями, що користуються попитом не тільки на локальних, але й глобальних ринках. Організація випуску товарів довготривалого зберігання, а також використання методів і технологій холодної логістики дозволяе транспортувати продукцію на далекі відстані, розширюючи часові межі ринку. Наступним етапом $\epsilon$ експорт інноваційних товарів, що, з одного боку, сприяє встановленню й посиленню зв'язків між локальним і глобальним ринками, взаємопроникненню місцевого ринку в світовий ринковий простір, з іншого, призводить до розширення географічних меж ринку, тобто його глокалізації.

Аналіз останніх публікацій по проблемі. Теоретико-методичні засади глокалізації економічних

* Публікація виконана в рамках наукового проекту «Розробка стратегій інноваційного розвитку для регіонів України на засадах глокалізації (на прикладі Одеської області)» за рахунок коштів бюджетної програми «Підтримка розвитку пріоритетних напрямів наукових досліджень» (КПКВК 6541230) 
процесів, у т.ч. ринкових, висвітлені в працях Батченко Л.В., Гончарова О.В., Жукова С.А., Кудряшової I.А., Осташко Т.О., Шавкуна І.Г. та інших науковців. Проблематиці інноваційного розвитку аграрної сфери регіонів присвячені дослідження Бородіної О.М., Дейнеко Л.В., Іртищевої І.О., Погріщука Б.В., Саблука П.Т. та інших учених. Водночас недостатньо дослідженим у науково-прикладному вимірі залишається питання стратегування інноваційного розвитку регіональних товарних ринків, у т.ч. агропродовольчих, на засадах глокалізації. Ці обставини обумовили мету і завдання даного дослідження.

Формулювання цілей дослідження. Мета статті - розробка сценаріїв та стратегічних орієнтирів інноваційного розвитку регіонального ринку зерна та продуктів його переробки в контексті глокалізації визначила низку завдань:

1) обгрунтувати методологічні аспекти глокалізації товарного ринку;

2) визначити ключові економічні інтереси регіону на ринку зерна й продуктів його переробки;

3) обгрунтувати стратегічні напрями й інструменти інноваційного розвитку регіонального ринку зерна та продуктів його переробки у глобальнолокальному вимірі.

Виклад основних результатів та їх обгрунтування. Методологічні основи глокалізації товарного ринку у двоєдності концептуального й методичного базисів, запропоновані автором, представлені на рис.1.

\begin{tabular}{|c|c|}
\hline & \\
\hline \multicolumn{2}{|c|}{$\begin{array}{l}\text { Мета глокалізації: ефективна інтеграція локальних ринків до глобального економічного простору на засадах } \\
\text { реалізації економічних інтересів регіону / держави }\end{array}$} \\
\hline \multicolumn{2}{|c|}{$\begin{array}{l}\text { Завдання ринкової глокалізації: } \\
\text { тивне функціонування локальних ринків (як регіональних, так і державного), оптимізація ринкової } \\
\text { вартості. } \\
\text { сізація зовнішньоекономічних загроз економічній безпеці держави. } \\
\text { аційний розвиток локальних ринків із врахуванням глобальних тенденцій 4. Ефективне використання } \\
\text { ого потенціалу локальних територій. } \\
\text { огічна орієнтованість процесу глокалізації, забезпечення екологічної безпеки ринків і територій. }\end{array}$} \\
\hline \multicolumn{2}{|r|}{ Принципи глокалізації товарних ринків } \\
\hline $\begin{array}{l}\text { 1.Пріоритет } \\
\text { номічних } \\
\text { держави / ре }\end{array}$ & $\begin{array}{l}\text { рективності п } \\
\text { інтересів окр } \\
\text { сів суспільств }\end{array}$ \\
\hline $\begin{array}{lr}\text { 2.Паритетність } & \text { лока- } \\
\text { льно-глобальних } & \text { взає- } \\
\text { модій } & \\
\end{array}$ & -глобальних вза \\
\hline 3. Ефрективність & \\
\hline 4. Екологічність & $\begin{array}{l}\text { iсть в } \\
\text { діяльн } \\
\text { сі глон }\end{array}$ \\
\hline 5. Формалізація & \\
\hline \multicolumn{2}{|r|}{ Методичний базис } \\
\hline \multicolumn{2}{|c|}{$\begin{array}{l}\text { 1. Ідентифікація релевантного ринку: товарні, територіальні та часові межі ринку, ємність, структура, } \\
\text { суб'єкти ринку, економічний потенціал розвитку. } \\
\text { 2. Оцінка ефективності глокалізації за допомогою груп показників: } \\
\text { 2.1. Група базових параметрів ринку: виробничих, трудових, фінансових, цінових; порівняльний аналіз по- } \\
\text { казників у просторово-часовому вимірі. } \\
\text { 2.2. Група інноваційних показників: оцінка інноваційного потенціалу регіону / ринку } \\
\text { 2.3. Група показників зовнішньоекономічної діяльності: структурно-динамічні зміни експортно-імпортних } \\
\text { операцій із певними видами товарів у регіоні } \\
\text { 2.4. Група специфічних показників: визначаються специфікою процесів відтворення певних товарних рин- } \\
\text { ків. } \\
\text { 3. Якісний аналіз причинно-наслідкових зв’язків, що визначають напрям глокалізації, } \\
\text { визначення негативних тенденцій, сукупності чинників впливу на її стан. } \\
\text { 4. Прогнозування розвитку процесу глокалізації і показників їі ефективності в регіоні }\end{array}$} \\
\hline \multicolumn{2}{|c|}{$\begin{array}{c}\text { Пріоритети національної / регіональної політики в ринковому вимірі, стратегічні орієнтири інноваційного } \\
\text { розвитку товарних ринків на засадах глокалізачії }\end{array}$} \\
\hline Механізми & тимулювання ефективної глокалізаиії стратегічних товарних ринків: \\
\hline
\end{tabular}

Рис. 1. Методологічні основи глокалізації товарного ринку*

*авторська розробка 
Метою глокалізації $є$ ефективна інтеграція локальних ринків до глобального простору на засадах реалізації економічних інтересів регіону / держави. Головні завдання ринкової глокалізації орієнтовані на досягнення іiї мети шляхом оптимізації загальної доданої вартості, створюваної в товарному ринку, мінімізації зовнішніх загроз економічній безпеці держави, інноваційного розвитку локальних ринків, ефективного використання ресурсного потенціалу локальних територій. Процес глокалізації товарних ринків базується на множині принципів, до яких віднесено пріоритетність економічних інтересів держави, паритетність локально-глобальних взаємодій ринкових суб'єктів, ефективність і екологічність процесу глокалізації, її формалізацію (див. рис. 1).

Головною складовою методичного базису постає 5-етапна діагностика стану процесу глокалізації товарних ринків. Другий етап передбачає оцінку ефективності глокалізаційних процесів за допомогою груп показників, зокрема, базових, інноваційних, зовнішньоекономічних та специфічних (див. рис. 1). Склад групи базових параметрів ринку визначається 3 урахуванням особливостей його товарних і часових меж, процесів відтворення ресурсів, а також наявністю інформаційної бази для оцінки. Група інноваційних показників передбачає оцінку інноваційного потенціалу регіону за допомогою різних методик [3, c.24-31]. Оскільки глокалізація товарного ринку передбачає активізацію експорту продукції регіональних виробників та розширення зовнішніх зв'язків, невід'ємною компонентою оціночного блоку є група показників зовнішньоекономічної діяльності. Склад групи специфічних показників визначається з урахуванням ринкових процесів відтворення; вона може включати коефіцієнти економічної та інноваційної спеціалізації, ресурсозабезпеченості, екологоорієнтованості та інші [4, с.29].

Діагностика процесу ринкової глокалізації передбачає якісний аналіз причинно-наслідкових зв'язків, що визначають іiі напрям, ідентифікацію негативних тенденцій, що не відповідають головній меті глокалізації, прогнозування ії стану й динаміки розвитку в регіоні (див. рис. 1). Результати проведеної діагностики формують аналітичне підгрунтя для розробки національної/регіональної політики в ринковому вимірі та механізмів їі впровадження (адміністративних, фінансово-економічних, інституційних та інформаційних) в стратегічних товарних ринках.

Особливості глокалізації та інноваційного розвитку ринків досліджено на прикладі аграрного ринку Одеської області. На підставі емпіричних досліджень визначено головні чинники, стримуючі стійкий інноваційний розвиток регіонального ринку, зокрема: незначний обсяг капітальних інвестицій в сільське господарство, відсутність розвинутої матеріально-технічної бази товаровиробників, низькі темпи зростання екологічних інвестицій, активізація ризиків екологічній безпеці регіону, незадовільний стан сфери поводження з відходами. Встановлено сировинний характер глокалізації агропродовольчого ринку, що генерує втрати доданої вартості та неефективне вико- ристання потужного природно-ресурсного потенціалу регіону [5, с.17 ].

Основою сталого відтворювального розвитку аграрного ринку Одеської області, гарантом іiї продовольчої й економічної безпеки є ринок зерна та продуктів його переробки. У видовій структурі сільськогосподарської продукції області частка зернових культур складає $37 \%$, експорту продуктів рослинного походження - $73 \%$ [6], що свідчить про вагому роль виробництва й експорту зерна в розвитку економіки регіону.

Проведені емпіричні дослідження [7] засвідчили наявність низки проблем, що гальмують впровадження інноваційної моделі у секторах зернового ринку. До головних проблем інноваційного розвитку ринку зерна та продуктів його переробки необхідно віднести, зокрема, низький рівень використання селекційного потенціалу області, звужене відтворення ресурсів в аграрному секторі ринку, нераціональну структура виробництва й збуту зернових культур, зростання обсягів позаелеваторного зберігання зерна та його втрат, незадовільний техніко-технологічний стан більшості елеваторів та зернопереробних підприємств, збільшення обсягів виробництва борошна й хліба у «тіньовому» сегменті, що стримує процес глокалізації ринку.

Сталий інноваційний розвиток ринку зерна та продуктів його переробки має важливе значення для його ефективної інтеграції до глобального економічного простору, забезпечення конкурентоспроможності як окремих суб'єктів ринку, так і економіки регіону в цілому. До головних економічних інтересів регіону на даному ринку доцільно віднести наступні:

- продовольче самозабезпечення регіону зерном, зерновими та хлібними продуктами для задоволення внутрішнього попиту населення і переробних підприємств області, імпортозаміщення готових харчових продуктів;

- забезпечення екологічної безпеки регіону, високої якості та екологічної безпеки зерна, зернових і хлібних продуктів, впровадження ресурсозберігаючих технологій і процесів у всіх секторах зернового ринку;

- формування сировинної бази, адаптованої до потреб регіональних переробних підприємств, стимулювання експорту їх товарів 3 високою доданою вартістю, освоєння перспективних напрямів зернопереробки;

- залучення суб'єктів індивідуального сектору до ринкової інфраструктури, зокрема секторів зберігання, розподілу й реалізації зерна, без посередницьких ланок на засадах паритетного розподілу доходів;

- підвищення рівня зайнятості населення регіону, створення додаткових робочих місць на переробних підприємствах;

- підтримка об'єднань регіональних агровиробників, які виконують важливі соціальноекономічні функції в розвитку локальних територій;

$$
\text { - ефективне використання природно- }
$$

ресурсного потенціалу регіону; 
- ефективне функціонування регіонального ринку зерна та продуктів його переробки, оптимізація створюваної в його межах доданої вартості.

У відповідності до методологічних основ ринкової глокалізації (див. рис. 1), ми пропонуємо виділити чотири сценарії інноваційного розвитку регіонального ринку зерна та продуктів його переробки (рис. 2). Наведені сценарії відображають взаємозв'язок між ступенем реалізації економічних інтересів регіону / держави та ступенем глокалізації досліджуваного ринку.

Сьогодні в Одеській області активно впроваджується перший сценарій, орієнтований на домінуючий експорт сировини (зерна) 3 низькою доданою вартістю (див. рис. 2). Проведені дослідження довели, що $95 \%$ валового зернового збору суб'єктів корпора- тивного сектору ринку експортується, водночас майже $90 \%$ внутрішнього зернового споживання забезпечують індивідуальні господарства [7, с.76]. Суб'єктне забезпечення продовольчої безпеки України та іiі регіонів здійснює індивідуальний сектор зернового ринку. Впровадження сценарію 1, 3 одного боку, не відповідає економічним інтересам регіону / держави, оскільки продукує значні втрати доданої вартості, як головного ресурсу інноваційного розвитку, з іншого, не забезпечує ефективну інтеграцію локального ринку до глобального, яка є головною метою ринкової глокалізації. В Одеській області та державі в цілому глокалізація носить сировинний характер, що не відповідає іiі економічним інтересам, не сприяє впровадженню інновацій в зерновій сфері та розвитку локальних територій.

\begin{tabular}{|c|c|c|}
\hline $\begin{array}{r}\text { Ступінь } \\
\text { локалізаціӥ } \\
\text { ринку }\end{array}$ & \\
\hline ринку & $\begin{array}{c}\text { Сценарій 3: } \\
\text { Виробництво й експорт } \\
\text { органічних зернових куль- } \\
\text { тур (зростаючий глобаль- } \\
\text { ний попит) }\end{array}$ & $\begin{array}{c}\text { Сценарій 4: } \\
\text { Зростання випуску та екс- } \\
\text { порту продуктів перероб- } \\
\text { ки зерна для потреб внут- } \\
\text { рішнього й зовнішнього } \\
\text { ринку }\end{array}$ \\
\hline Низький & $\begin{array}{c}\text { Сценарій 1: } \\
\text { Домінуючий експорт си- } \\
\text { ровини з низькою доданою } \\
\text { вартістю (корпоративний } \\
\text { сектор ринку) }\end{array}$ & $\begin{array}{c}\text { Сценарій 2: } \\
\text { Зростання випуску проду- } \\
\text { ктів переробки на іннова- } \\
\text { ційній основі для потреб } \\
\text { внутрішнього ринку }\end{array}$ \\
\hline & Низький & $\begin{array}{l}\text { Ступінь } \\
\text { регіону/с }\end{array}$ \\
\hline
\end{tabular}

\author{
Скорочення: EI* - економічні інтереси \\ Рис. 2. Сценарії інноваційного розвитку регіонального ринку зерна та \\ продуктів його переробки* \\ *авторська розробка
}

Другий сценарій інноваційного розвитку орієнтований на зростання випуску продуктів переробки зерна на інноваційній основі для потреб внутрішнього ринку (див. рис. 2). Даний сценарій передбачає ефективне використання ресурсного потенціалу регіону, отримання відтворювального, соціального й податкового ефектів у регіональній системі, що відповідає іiі інтересам. Водночас орієнтація тільки на внутрішній ринок, відсутність зовнішніх просторових взаємодій є свідченням низького рівня глокалізації.

Слід відзначити реалізацію сценарію 2 на круп'яному ринку Одеської області. Так, у 20162017 pр. обсяги круп'яного виробництва в області зросли в 10 разів порівняно з 2010 р. і досягли 14,6 \% від державного випуску круп [6]. Водночас нарощування внутрішнього виробництва круп не супроводжувалося збільшенням обсягів їх експорту. Перспективними напрямами глокалізації круп'яного ринку області є випуск інноваційних видів продукції для потреб зовнішнього ринку, виробництво органічних товарів.

Третій сценарій інноваційного розвитку ринку передбачає виробництво органічних зернових культур на локальних територіях та їх експорт на зовнішні ринки збуту у відповідності до стабільно зростаючого глобального попиту. В умовах стагнації зовнішнього попиту на сировинні товари, передусім зерно, що проявляється тенденцією зниження їх світових цін, глобальний попит на органічні культури та продукти їх переробки перманентно зростає. У країнах ЄC сегмент органічної сировини не заповнений, щорічний приріст обсягів споживання екотоварів досягає $10 \%$. Орієнтація локального зернового ринку на третій сценарій інноваційного розвитку, з огляду на зростання глобального попиту та сприятливу цінову кон'юнктуру, забезпечує високий рівень глокалізації ринку за низького ступеня реалізації економічних інтересів регіону / держави, оскільки, як і в сценарії 1, 
йдеться про сировинний експорт.

За площею органічних угідь Україна посідає 11 місце в Європі (381 тис. га), однак це лише $1 \%$ державних сільгоспугідь. Одеська область має найбільшу площу сертифікованих органічних земель (102 тис. га) та найбільшу кількість органічних господарств в Україні [8]. Враховуючи потужний ресурсний потенціал органічного виробництва, перспективним напрямом розвитку області може стати вирощування й переробка органічного зерна для потреб внутрішнього й зовнішнього ринку. В такому випадку третій сценарій трансформується в четвертий, що відповідає інтересам регіону (див. рис. 2). При цьому важливо залучити суб'єктів індивідуального сектору зернового ринку до освоєння органічного сегменту, для зміцнення їх фінансової основи інноваційного розвитку. Органічна націнка в Європі складає 50$60 \%$, а в Україні - лише 30-40 \%, що значно приваблює трейдерів [9]. Нині експорт органічної сировини здійснюють суб'єкти корпоративного сектору ринку, які спроможні сформувати великі товарні партії; індивідуальні господарства реалізують продукцію на внутрішньому ринку, втрачаючи частину прибутку. Тому постає необхідність їх об'єднання в органічні кооперативи.

Четвертий сценарій передбачає поетапне зростання регіонального випуску та експорту зернових і хлібних продуктів (у т.ч. органічних) для задоволення потреб як внутрішнього, так і зовнішнього ринків (див. рис. 2). Впровадження даного сценарію генерує високий ступінь реалізації економічних інтересів регіону / держави, оскільки продукує додану вартість в їх межах, та високий рівень глокалізації ринку шляхом зміни його сировинної спрямованості на переробну, освоєння нових ринків збуту та впровадження довгострокових маркетингових стратегій локальних товаровиробників.

Слід відзначити, що сценарій 4 інноваційного розвитку зернового ринку відповідає Експортній стратегї («дорожній карті» стратегічного розвитку торгівлі) Украӥни на 2017-2021 роки [9]. У документі зазначено, що вітчизняний експорт складається переважно із сировини (70 \% експорту в 2016 р.). Це свідчить про неефективне використання ресурсів, ставить українську економіку в залежність від коливань цін на світових ринках і містить потенційні ризики для економічної і соціальної стабільності. Метою Стратегії є перехід України до експорту наукомісткої інноваційної продукції для сталого розвитку та успішного виходу на світові ринки. Однією зі стратегічних цілей розвитку торгівлі України визначено створення сприятливих умов, що стимулюють торгівлю та інновації для диверсифікації експорту [9].

До пріоритетних секторів економіки для розвитку експорту в Експортній стратегії України віднесено, зокрема, сектор харчової і переробної промисловості. При цьому найбільшу перспективу в даному секторі представляють готові продукти харчування, харчові інгредієнти та органічна продукція. Харчова i переробна промисловість ввійшла до складу секторів, які перебувають на стадії швидкого зростання. В Ек- спортній стратегії вказано, що такі сектори повинні використовувати існуючі можливості на зовнішніх ринках та продукувати складову доданої вартості [9].

Для реалізації четвертого сценарію необхідними є розробка та впровадження стратегічних напрямів інноваційного розвитку ринку зерна та продуктів його переробки та системи заходів управлінського впливу. Управління інноваційним розвитком регіонального ринку зерна та продуктів його переробки на засадах глокалізації можна трактувати як цілеспрямований вплив суб'єктів управління (суб'єктів господарювання, їх об'єднань, профільних інституцій, державних органів влади та інших стейкхолдерів) на процес відтворення ресурсів у секторах ринку з метою випуску нових конкурентоспроможних товарів i послуг, впровадження сучасних ресурсозберігаючих технологій і процесів, нових методів управління, що істотно поліпшить структуру і якість виробництва та збуту зернової продукції на основі наукових розробок, розширить товарні й територіальні межі ринку та диверсифікує експорт аграрної продукції.

Головні стратегічні напрями, за якими доцільно здійснювати управління інноваційним розвитком релевантного ринку, та інструменти управлінського впливу, розроблені автором на підставі проведених емпіричних досліджень, узагальнені в табл.1.

Для сектору вирощування зернових культур на локальному ринку основними стратегічними напрямами є використання інноваційного селекційного потенціалу, зміна структури виробництва й реалізації зерна з експортної на переробну спрямованість шляхом посилення прямих зв'язків аграріїв з переробними підприємствами, розширення збутових каналів за рахунок державного та кооперативного каналів, стимулювання об'єднання індивідуальних господарств у зернові обслуговуючі кооперативи (див. табл. 1). Останній напрям для Одеської області є пріоритетним з огляду на значну роль індивідуального сектору в розвитку агросфери та високі потенційні можливості кооперативів в організації ефективної логістики зернового ринку, подоланні залежності від цінової політики трейдерів та монопольних елеваторів, забезпеченні доступу до бюджетних коштів та цільових програм.

Обслуговуюча кооперація може стати дієвим механізмом виходу суб'єктів індивідуального сектору на зовнішні ринки збуту за умови стимулювання переробки органічного зерна в органічних кооперативах на основі європейського досвіду. У Європі органічне виробництво є дрібнотоварним бізнесом, що забезпечує формування місцевих продовольчих систем і розвиток мікрофермерства. Зайняття ринкової ніші органічного зерновиробництва дозволить фермерським i особистим селянським господарствам підвищити ефективність діяльності за рахунок високої рентабельності органічного зерна й зернопродуктів, організації їх експортних продаж без посередників. Головними інструментами підтримки органічного руху в регіонах України можуть бути пільги і преференції кооперативам із переробки органічної сировини, часткове бюджетне фінансування будівництва їх 
Стратегічні напрями й інструменти інноваційного розвитку регіонального ринку зерна та продуктів його переробки на засадах глокалізації

\begin{tabular}{|c|c|c|}
\hline Ринки & Стратегічні напрями & Інструменти \\
\hline \multicolumn{3}{|c|}{ Сектор вирощування зернових культур } \\
\hline 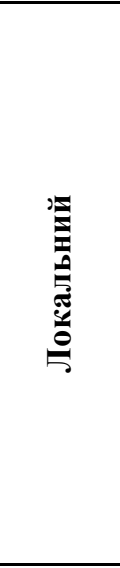 & $\begin{array}{l}\text { 1. Використання потенціалу вітчизняної } \\
\text { селекції } \\
\text { 2. Зміна структури виробництва й реалі- } \\
\text { зації зерна у відповідності до потреб пе- } \\
\text { реробних підприємств } \\
\text { 3. Об’єднання індивідуальних госпо- } \\
\text { дарств у кооперативи } \\
\text { 4. Раціональне використання зрошува- } \\
\text { них земель } \\
\text { 5. Впровадження інноваційних техноло- } \\
\text { гій у зерновиробництво } \\
\text { 6. Науково-інноваційне оновлення агро- } \\
\text { сфери регіону }\end{array}$ & $\begin{array}{l}\text { 1. Часткова компенсація вартості сертифікованого на- } \\
\text { сіння для аграріїв } \\
\text { 2. Диверсифікація каналів збуту зерна за рахунок дер- } \\
\text { жавного й кооперативного } \\
\text { 3. Формування й розвиток прямих зв’язків виробників } \\
\text { і переробників зерна } \\
\text { 4. Державна підтримка створення мережі аграрних } \\
\text { обслуговуючих кооперативів } \\
\text { 5. Фінансова й інформаційна підтримка кооперативно- } \\
\text { го руху в регіонах } \\
\text { 6. Часткове здешевлення вартості техніки, пільгове } \\
\text { кредитування виробників } \\
\text { 7.Стимулювання впровадження наукових розробок і } \\
\text { винаходів в агросферу }\end{array}$ \\
\hline 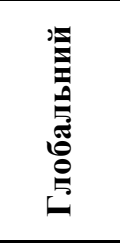 & $\begin{array}{l}\text { 1. Експорт органічного зерна та продук- } \\
\text { тів його переробки } \\
\text { 2. Вихід органічних кооперативів на зов- } \\
\text { нішні ринки збуту } \\
\text { 3. Імпортозаміщення зерна та продуктів } \\
\text { його переробки }\end{array}$ & $\begin{array}{l}\text { 1. Залучення бюджетних коштів для будівництва по- } \\
\text { тужностей із переробки органічної сировини } \\
\text { 2. Пільги і преференції кооперативам із переробки } \\
\text { органічної сировини } \\
\text { 3. Інформаційне забезпечення становлення й розвитку } \\
\text { зовнішніх кооперативних зв’язків }\end{array}$ \\
\hline \multicolumn{3}{|c|}{ Сектор зберігання й доробки зерна } \\
\hline 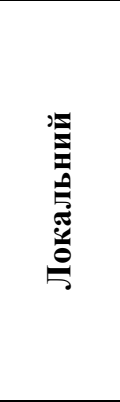 & $\begin{array}{l}\text { 1. Зменшення обсягів позаелеваторного } \\
\text { зберігання зерна } \\
\text { 2. Підвищення якості зерно-зберігаючих } \\
\text { послуг діючими елеваторами } \\
\text { 3. Створення кооперативних елеваторів } \\
\text { на базі інноваційних технологій } \\
\text { 4. Інноваційна модернізація техніко- } \\
\text { технологічного стану діючих зернових } \\
\text { складів }\end{array}$ & $\begin{array}{l}\text { 1.Оптимізація співвідношення якість/тарифи послуг } \\
\text { зберігання } \\
\text { 2. Гнучка система розрахунків за надані послуги, від- } \\
\text { строчка платежів } \\
\text { 3. Стимулювання створення кооперативних елеваторів } \\
\text { з використанням механізму державно-приватного пар- } \\
\text { тнерства } \\
\text { 4. Пільгові кредити для техніко-технологічної модер- } \\
\text { нізації зернових складів на основі інноваційних розро- } \\
\text { бок }\end{array}$ \\
\hline 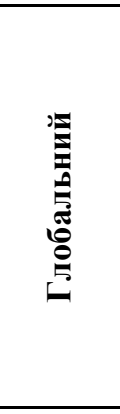 & $\begin{array}{l}\text { 1.Застосування інноваційних методів } \\
\text { зберігання зерна } \\
\text { (КА технологій, консервування зерна } \\
\text { охолодженням та ін.) } \\
\text { 2. Впровадження інноваційних методів } \\
\text { управління суб'єктами (аутсорсинг, аут- } \\
\text { стафінг) } \\
\text { 3. Проведення об'єктивних якісних ла- } \\
\text { бораторних досліджень зерна за євро- } \\
\text { пейськими стандартами }\end{array}$ & $\begin{array}{l}\text { 1. Зберігання зернових культур на елеваторах персо- } \\
\text { ніфікованими партіями } \\
\text { 2. Адаптація вітчизняної системи зернозберігання до } \\
\text { європейських стандартів і нормативів } \\
\text { 3. Створення системи ефективних логістичних зв'язків } \\
\text { 3 постачальниками } \\
\text { 4. Організація роботи незалежних регіональних лабо- } \\
\text { раторій якості агропродукції щодо визначення класу } \\
\text { зерна в процесі його надходження від виробників до } \\
\text { елеваторів }\end{array}$ \\
\hline \multicolumn{3}{|c|}{ Сектор виробництва зернової продукції } \\
\hline 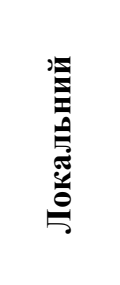 & $\begin{array}{l}\text { 1. Організація випуску інноваційних ви- } \\
\text { дів продукції: борошняних композицій- } \\
\text { них сумішей, борошна із мікронутрієн- } \\
\text { тами, із зерна пророщеної пшениці та ін. } \\
\text { 2. Виробництво продуктів швидкого } \\
\text { приготування (пластівці, мюслі тощо) }\end{array}$ & $\begin{array}{l}\text { 1. Стимулювання впровадження екологічно чистих } \\
\text { технологій у зернопереробне виробництво } \\
\text { 2. Пільгові кредити для техніко-технологічної модер- } \\
\text { нізації переробних підприємств на інноваційній основі } \\
\text { 3. Організація державних інтервенцій борошном із } \\
\text { мікронутрієнтами } \\
\text { 4. Розбудова ефективної логістики ринку }\end{array}$ \\
\hline
\end{tabular}


Продовження табл.1

\begin{tabular}{|c|c|c|}
\hline Ринки & Стратегічні напрями & Інструменти \\
\hline 章 & $\begin{array}{l}\text { 3.Виробництво продуктів оздоровчого } \\
\text { призначення } \\
\text { 4. Відновлення виробництва борошна із } \\
\text { пшениці твердих сортів; житнього бо- } \\
\text { рошна }\end{array}$ & $\begin{array}{l}\text { 5. Погектарні дотації аграріям за виробництво продо- } \\
\text { вольчого зерна із заданими параметрами якості (зок- } \\
\text { рема, пшениці твердих сортів, жита) }\end{array}$ \\
\hline 罸 & $\begin{array}{l}\text { 1. Забезпечення конкурентоспроможнос- } \\
\text { ті українського борошна на світовому } \\
\text { ринку (диверсифікація асортименту та } \\
\text { ринків збуту, вітамінізація) } \\
\text { 2. Підвищення доходності експорту віт- } \\
\text { чизняного борошна } \\
\text { 3. Освоєння зовнішніх ринків збуту } \\
\text { українського борошна, реалізація довго- } \\
\text { строкових ринкових стратегій }\end{array}$ & $\begin{array}{l}\text { 1. Моніторинг тенденцій інноваційного розвитку сві- } \\
\text { тового ринку зернопродуктів } \\
\text { 2. Часткова компенсація транспортних витрат експор- } \\
\text { терів борошна, вартості міжнародної сертифікації під- } \\
\text { приємств } \\
\text { 3. Переорієнтація ПАТ «ДПЗКУ» }{ }^{* *} \text { з експорту зерна на } \\
\text { зернопродукти } \\
\text { 4.Активна діяльність ГС «Борошномели України», їі } \\
\text { тісна співпраця з державними інституціями } \\
\text { 5. Розробка та впровадження національної програми } \\
\text { збагачення борошна мікронутрієнтами } \\
\text { 6. Створення інституцій підтримки експорту перероб- } \\
\text { ної продукції }\end{array}$ \\
\hline \multicolumn{3}{|c|}{ Сектор виробництва хлібної продукції } \\
\hline 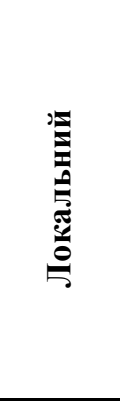 & $\begin{array}{l}\text { 1. Виробництво інноваційних видів про- } \\
\text { дукції: з використанням солодових екст- } \\
\text { рактів, нетрадиційних видів начинки, } \\
\text { лікувально-профілактичного призначен- } \\
\text { ня } \\
\text { 2. Впровадження інноваційних техноло- } \\
\text { гічних процесів } \\
\text { 3. Поетапна інтеграція «тіньового» сег- } \\
\text { менту в структуру офіційного хлібного } \\
\text { ринку }\end{array}$ & $\begin{array}{l}\text { 1.Стимулювання впровадження енергоефективних } \\
\text { ресурсозберігаючих технологій у виробництво } \\
\text { 2. Пільгові кредити для технічного оновлення хлібо- } \\
\text { пекарських підприємств на інноваційній основі } \\
\text { 3. Податкові преференції для соціально орієнтованих } \\
\text { хлібовиробників } \\
\text { 4. Реформування системи ринкового нагляду з вико- } \\
\text { ристанням європейського досвіду та за участі держав- } \\
\text { них і профільних інституцій }\end{array}$ \\
\hline 产 & $\begin{array}{l}\text { 1. Виробництво та експорт хлібопродук- } \\
\text { тів тривалого зберігання, заморожених } \\
\text { напівфабрикатів та ін. } \\
\text { 2. Освоєння нових ринків збуту } \\
\text { 3. Імпортозаміщення готових хлібних } \\
\text { продуктів }\end{array}$ & $\begin{array}{l}\text { 1. Моніторинг тенденцій інноваційного розвитку сві- } \\
\text { тового ринку хлібопродуктів } \\
\text { 2. Створення інституцій підтримки експорту харчової } \\
\text { продукції } \\
\text { 3.Розвиток зовнішніх зв’язків між профільними інсти- } \\
\text { туціями локального й глобального ринків }\end{array}$ \\
\hline
\end{tabular}

* Розроблено автором $з$ використанням джерел [7, 10, 11, 12].

** ПАТ «ДПЗКУ» - Державна продовольчо-зернова корпорація України.

переробних потужностей, інформаційне забезпечення формування й розвитку глобальних зв'язків між вітчизняними та іноземними кооперативами.

Стратегія інноваційного розвитку сектору зберігання й доробки зерна орієнтована на вирішення його ключових проблем на локальному ринку і передбачає, насамперед, зменшення обсягів позаелеваторного зберігання зерна, підвищення якості послуг зернових складів, модернізацію їх технікотехнологічного стану на основі інноваційних розробок (див. табл. 2). В українських реаліях актуалізується завдання будівництва сучасних кооперативних елеваторів із використанням механізму державноприватного партнерства. Для ефективної інтеграції сектору в глобальний ринок доцільними $є$ застосування нових методів зберігання зерна (КА технологій, консервування зерна охолодженням, методу «Силобег» [11]), інноваційних методів управління підприємством (аутсорсингу, аутстафінгу [12]), проведення об'єктивних лабораторних досліджень зерна незалежними лабораторіями якості в регіонах. Для впровадження стратегічних напрямів інноваційного розвитку сектору необхідним $є$ поєднання інструментів впливу як суб'єктів ринку, так і держави.

Для суб'єктів господарювання, що здійснюють діяльність у секторі виробництва зернових продуктів на локальному ринку, стратегічним напрямом розвитку є освоєння випуску інноваційних видів продукції (борошна із мікронутрієнтами, із зерна пророщеної пшениці, продуктів швидкого приготування, оздоровчого призначення тощо) та відновлення виробництва борошна із твердої пшениці для потреб макаронної промисловості (див. табл. 2). Також важливим завданням на шляху інноваційного розвитку сектору постає впровадження сучасних ресурсозаощадливих технологій, відновлення якісної сировинної бази шляхом дотування аграріїв, які вирощують продовольчі культури із заданими параметрами якості 
(зокрема, твердої пшениці, жита).

Сьогодні борошняний ринок України є потенційним джерелом диверсифікації аграрного експорту, зростання в його структурі частки товарів з високою доданою вартістю. В умовах обмеженого внутрішнього попиту головним стратегічним напрямом відтворювального й інноваційного розвитку даного ринку $є$ його ефективна інтеграція до глобального ринку шляхом підвищення конкурентоспроможності вітчизняної борошномельної продукції, диверсифікаціï іiі асортименту, освоєння нових ринків збуту, впровадження ринкових (однак не цінових) експортних стратегій. У перспективі головною складовою конкурентної стратегії вітчизняних експортерів БКП на глобальному ринку повинна стати не цінова конкуренція (нині головною конкурентною перевагою українського борошна є низька ціна), а впровадження ринкових стратегій, які передбачають забезпечення диверсифікації і розширення ринків збуту, постачань сировини й товарів для національної економіки [13, c. 5].

Слід відзначити перші успішні кроки в диверсифікації експорту українського борошна, що дозволило вітчизняним експортерам закріпити свої позиції на ринках Азії (33\% експорту в 2016 р.), Близького Сходу (23\%) та Африки (16\%) [14]. Водночас необхідно реалізовувати іншу складову ринкових стратегій, пов'язану з формуванням нових товарних і географічних ринків продукції власного виробництва. Сьогодні в країнах Азії формуються нові продовольчі ринки і нова культура споживання, відтак, українські виробники здатні зайняти в них сегмент високоякісної продукції з помірними цінами й стати альтернативою західним товарам [13, с. 5].

У напрямі становлення нових ринків унікальних товарів українським виробникам БКП доцільно розширити товарний асортимент, організувати випуск інноваційних видів продукції, розвивати органічний та вітамінізований напрями виробництва. При цьому асортимент продукції, а також способи їі фасування, упаковки й маркування необхідно адаптувати до вимог країни-імпортера. У більшості держав - імпортерів борошномельної продукції діють вимоги щодо ii збагачення мікронутрієнтами (вітамінами i мікроелементами). Враховуючи світовий досвід, доцільно розробити національну програму збагачення борошномельної продукції мікронутрієнтами та механізми іiі реалізації (зокрема, державні інтервенції вітамінізованого борошна), залучивши до цього заходу Громадську Спілку «Борошномели України» й державні інституції. Реалізація даної програми сприятиме інтеграції локального ринку зернових продуктів до глобального ринкового простору.

Впровадження інноваційної моделі розвитку в секторі виробництва хлібопродуктів на локальному ринку передбачає випуск інноваційних видів продукції (зокрема, з використанням солодових екстрактів, нетрадиційних видів начинки, лікувальнопрофілактичного призначення), розширення асортименту, використання інноваційних технологічних процесів (див. табл. 5.18). Поетапній інтеграції «ті- ньового» сегменту в структуру офіційного ринку сприятиме реформування системи ринкового нагляду за участю державних і профільних інституцій, ресурсному забезпеченню інноваційного процесу - пільгове кредитування модернізації хлібопекарських виробництв, послаблення податкового навантаження для соціально орієнтованих підприємств, зокрема, запровадження пільгової ставки ПДВ для реалізації хліба та хлібобулочних виробів нетривалого зберігання 3 використанням досвіду країн СС.

Головним стратегічним напрямом інноваційного розвитку сектору на глобальному ринку $\epsilon$ випуск та експорт інноваційних видів хлібопродуктів тривалого зберігання і заморожених напівфабрикатів, освоєння нових ринків збуту та поетапне імпортозаміщення готових хлібних продуктів. Для глокалізації хлібного ринку доцільним $є$ моніторинг тенденцій інноваційного розвитку світового ринку хлібопродуктів, створення й активна діяльність інституцій підтримки експорту харчової продукції (зокрема, Офісу 3 просування експорту при Мінекономрозвитку, Експортно-кредитного агентства [10]), формування зовнішніх зв'язків профільних інституцій ринку.

Таким чином, запропоновані стратегічні напрями та інструментарій інноваційного розвитку регіонального ринку зерна та продуктів його переробки орієнтовані на реалізацію економічних інтересів регіону / держави, зміну сировинного характеру ринкової глокалізації, диверсифікацію українського агропродовольчого експорту шляхом нарощування в його структурі частки товарів з високою доданою вартістю, поетапне імпортозаміщення зернових і хлібних продуктів, ефективне використання ресурсного потенціалу локальних територій для отримання відтворювального, соціального та податкового ефектів у регіональній і національній економічній системі.

Висновки та перспективи подальших досліджень. Обгрунтовано методологічні аспекти ринкової глокалізації, що базуються на множині принципів (пріоритетність економічних інтересів держави / регіону, паритетність локально-глобальних взаємодій, ефективність, екологічність, формалізація), чотирьохетапній діагностиці процесів глокалізації товарних ринків, результати якої формують наукове й аналітичне підгрунтя для розробки стратегій і механізмів інноваційного розвитку регіональних ринків на засадах глокалізації.

Визначено основні економічні інтереси регіону на ринку зерна та продуктів його переробки 3 акцентом на забезпечення продовольчої й екологічної безпеки регіону, ефективне використання ресурсного потенціалу локальних територій, оптимізацію ринкової доданої вартості. У відповідності до методологічних основ ринкової глокалізації виділено чотири сценарії інноваційного розвитку регіонального ринку зерна та продуктів його переробки, які відображають взаємозв'язок між ступенем реалізації економічних інтересів регіону та ступенем глокалізації даного ринку. Доведено доцільність впровадження четвертого сценарію, орієнтованого на зростання виробництва й експорту зернових і хлібних продуктів, що генерує 
одночасно високий ступінь глокалізації ринку та реалізації економічних інтересів регіону.

На підставі проведених емпіричних досліджень обгрунтовано стратегічні напрями й інструменти інноваційного розвитку регіонального ринку зерна та продуктів його переробки на засадах глокалізаціï. Їх головний вектор орієнтовано на забезпечення ефективної інтеграції локального ринку до глобального простору на засадах впровадження економічних інтересів регіону / держави, зміну спрямованості ринкової глокалізації з сировинної на переробну, впровадження прогресивних ресурсозаощадливих технологій у всіх секторах ринку, поетапне імпортозаміщення продуктів переробки для нарощування доданої вартості, як головного ресурсу сталого інноваційного розвитку ринку.

Наукова новизна проведеного дослідження полягає в обгрунтуванні методологічних аспектів ефективної глокалізації товарних ринків у двоєдності концептуального та методичного базисів, визначенні сценаріїв інноваційного розвитку регіонального ринку зерна та продуктів його переробки на основі взаємозалежності між рівнем реалізації регіональних інтересів та ступенем ринкової глокалізації. Практичне значення результатів дослідження визначається можливістю їх використання державними й профільними інституціями в ході розробки стратегічних напрямів та інструментів інноваційного розвитку регіонального ринку зерна та продуктів його переробки у локально-глобальному вимірі. Перспективи подальших досліджень полягають в обгрунтуванні потенційних сценаріїв і напрямів інноваційного розвитку стратегічних агропродовольчих ринків України у контексті глокалізації з використанням запропонованого у статті методологічного базису.

\section{Література}

1. Жуков С.А. Глокалізація як сучасний і перспективний процес розвитку світового господарства та міжнародних економічних відносин. Науковий вісник Ужгородського університету. 2014. Серія Економіка. Вип. 3(44). С.199-201.

2. Нікішина О.В. Сучасні тенденції глокалізації агропродовольчих ринків Одеської області. Актуальні проблеми теорії та практики менеджменту: матер. VIII міжнар. наук.-практ. конф., 28 травня 2019 р. Одеса: ОНПУ, 2019. С. 177-179.

3. Буркинський Б.В., Лазарєва Є.В. Інноваційна стратегія у соціально-економічному розвитку регіону. Одеса: ІПРЕЕД НАН України, 2007. 140 с.

4. Methodical Toolkit of Strategizing of Innovative Development of Regions on the Principles of Glocalization of Economic Processes: monograf / [O.A. Iermakova and others]; under the scientific editorship of O.A. Iermakova; - Odessa: IMPEER NASU, 2019. - 55 p.

5. Нікішина О.В. Сучасні вектори інноваційного розвитку та глокалізації аграрного ринку Одеської області. Актуальні проблеми сучасного управління в соціально-економічних, гуманітарних та технічних системах: зб. наук. праць МАУП. Одеса: Ледадрук, 2019. С. 10-24.

6. Статистичний щорічник Одеської області за 2017 рік / за ред. Т. В. Копилової. Одеса: Головне управління статистики в Одеській області, 2018. 421 с.

7. Нікішина О.В., Бібікова Н.О. Розвиток регіональних обслуговуючих кооперативів зернового ринку: інтеграційний підхід: монографія. Одеса: ІПРЕЕД НАН України, 2018. 230 с.

8. П'ять фактів про органічне землеробство в Україні. URL: https://bakertilly.ua/news/id45259 (дата звернення 12.08.2019).

9. Мармуль Л. О., Новак Н.П. Розвиток органічного виробництва в Україні на засадах кооперації. Економіка АПК. 2016. № 9. С. 26-32.

10. Експортна стратегія («дорожня карта» стратегічного розвитку торгівлі) України на 2017-2021 роки. Затверджено Розпорядженням Кабінету Міністрів України № 1017-p від 27 грудня 2017 p. URL: http://zakon2.rada.gov.ua/laws/show/1017-2017-\%D1\%80 (дата звернення 21.09.2019).

11. Савенко I.I., Седікова I.О. Організаційно-економічний механізм функціонування підприємств зернового підкомплексу: монографія. Одеса: Поліграф, 2012. 175 с.

12. Седікова І.О. Інноваційні методи управління підприємствами зернопродуктового підкомплексу. Бізнес Інформ. 2013. №1. С.114-117.

13. Липов В.В. Конкурентная стратегия Украины в условиях глобализации. Экономика Украины. 2018. №4. С. 3-17.

14. Ринок зерна України: від експорту сировини до готової продукції. 13.09.2017. URL: https://agronews.ua/node/82481 (дата звернення 20.09.2019). 


\author{
Никишина О.В. \\ доктор экономических наук, старший научный сотрудник \\ заведующий отдела рыночных механизмов и структур \\ Институт проблем рынка и экономико-экологических исследований НАН Украины \\ Французский бульвар, 29, г.Одесса, Украина, 65044 \\ E-mail: ksenkych@gmail.com \\ ORCID ID: 0000-0002-7172-3551
}

\title{
СЦЕНАРИИ И СТРАТЕГИЧЕСКИЕ НАПРАВЛЕНИЯ ИННОВАЦИОННОГО РАЗВИТИЯ РЕГИОНАЛЬНОГО РЫНКА ЗЕРНА И ПРОДУКТОВ ЕГО ПЕРЕРАБОТКИ НА ОСНОВЕ ГЛОКАЛИЗАЦИИ
}

\begin{abstract}
В статье обоснованы методологические аспекты глокализации товарных рынков, акцентировано внимание на целевом ориентире данного процесса - обеспечение эффективной интеграции локальных рынков в глобальное пространство на основе реализации экономических интересов региона / страны. Определены основные принципы рыночной глокализации, а именно: приоритетность экономических интересов государства / региона, паритетность локально-глобальных взаимодействий, эффективность, экологичность, формализация. Предложено четырехэтапную процедуру диагностики глокализации товарных рынков, результаты которой фрормируют аналитическую базу для разработки стратегий и механизмов инновационного развития региональных рынков на основе глокализации.

Определены главные проблемы инновационного развития стратегического рынка зерна и продуктов его переработки в Одесской области. Отмечено, что в Одесской области и стране в целом рыночная глокализация носит сырьевой характер, что не соответствует их экономическим интересам и не способствует внедрению инноваций в зерновой сфере и развитию локальных территорий. Обоснованы основные экономические интересы региона на рынке зерна и продуктов его переработки с акцентом на обеспечение продовольственной и экологической безопасности региона, эффективное использование его ресурсного потенциала, оптимизацию рыночной добавленной стоимости.

В соответствии с методологическими основами рыночной глокализации выделено четыре сценария инновационного развития регионального рынка зерна и продуктов его переработки, отражающие взаимосвязь между степенью реализации экономических интересов региона и степенью глокализации данного рынка. Доказана целесообразность внедрения четвертого сценария, ориентированного на рост производства и экспорта зерновых и хлебных продуктов.

По результатам эмпирических исследований обоснованы стратегические направления и инструменты инновационного развития регионального рынка зерна и продуктов его переработки на основе глокализации. Акцентировано внимание на изменение вектора рыночной глокализации с сырьевого на перерабатывающий, внедрение прогрессивных ресурсосберегающих технологий во всех секторах рынка, поэтапное импортозамещение продуктов переработки для наращивания добавленной стоимости, как главного ресурса устойчивого инновационного развития рынка.

Ключевые слова: глокализация, товарный рынок, инновационное развитие, рынок зерна и продуктов его переработки, экономические интересы региона.
\end{abstract}

Nikishyna 0.

Doctor of Economics, Senior Researcher

Head of Department of Market Mechanisms and Structures

Institute of Market Problems and Economic \& Ecological Research

of National Academy of Sciences of Ukraine

Frantsuzskiy boulevard, 29, Odesa, Ukraine, 65044

E-mail: ksenkych@gmail.com

ORCID ID: 0000-0002-7172-3551

\section{SCENARIOS AND STRATEGIC DIRECTIONS OF INNOVATIVE DEVELOPMENT OF THE REGIONAL MARKET OF GRAIN AND PRODUCTS OF ITS PROCESSING ON THE BASIS OF GLOCALIZATION}

In the article the methodological aspects of commodity market glocalization have been grounded, attention has been focused on the target orientation of this process - ensuring effective integration of local markets into the global space on the basis of realization of economic interests of the region / state. The main principles of market glocalization has been defined, namely: priority of economic interests of the state / region, parity of local-global interactions, efficiency, ecology, formalization. A four-stage procedure for diagnostics of commodity market glocalization is proposed, the results of which form an analytical basis for the development of strategies and mechanisms for innovative development of regional markets on the basis of glocalization. 
The main problems of innovative development of strategic grain market and products of its processing in Odessa region have been identified. It has been noted that in Odessa region and the country as a whole, market glocalization is of a raw material nature that does not correspond to their economic interests and does not facilitate the introduction of innovations in the grain field and the development of local territories. The basic economic interests of the region in the grain market and products of its processing with the emphasis on ensuring the food and environmental security of the region, efficient use of its resource potential, optimization of market added value have been substantiated.

In accordance with the methodological bases of market glocalization, four scenarios of innovative development of the regional grain market and its products have been identified, reflecting the relationship between the degree of realization of the economic interests of the region and the degree of glocalization of the market. The feasibility of implementing the fourth scenario, focused on increasing the production and export of grain and bread products, has been proved.

According to the results of empirical research, strategic directions and instruments of innovative development of the regional grain market and products of its processing on the basis of glocalization have been substantiated. The emphasis is on changing the vector of market glocalization from raw materials to processing, introduction of advanced resource-saving technologies in all sectors of the market, gradual import substitution of processing products for increasing value added, as the main resource for sustainable innovative market development.

Key words: glocalization, commodity market, innovative development, market of grain and its products processing, economic interests of the region.

\section{References}

1. Zhukov, S. A. (2014). Hlokalizatsiia yak suchasnyi i perspektyvnyi protses rozvytku svitovoho hospodarstva ta mizhnarodnykh ekonomichnykh vidnosyn. Naukovyi Visnyk Uzhhorodskoho Universytetu, (3 (44), 199-201.

2. Nikishyna, O. V. (2019). Suchasni tendentsii hlokalizatsii ahroprodovolchykh rynkiv Odeskoi oblasti. In Aktualni problemy teorii ta praktyky menedzhmentu: mater. VIII mizhnar. nauk. -prakt. konf., 28 travnia 2019 r. (pp. 177-179). Odesa: ONPU.

3. Burkynskyi, B. V., \& Lazarieva, Ye. V. (2007). Innovatsiina stratehiia u sotsialno-ekonomichnomu rozvytku rehionu. Odesa: IPREED NAN Ukrainy.

4. Iermakova, O. A. (Ed.). (2019). Methodical Toolkit of Strategizing of Innovative Development of Regions on the Principles of Glocalization of Economic Processes. Odessa: IMPEER NASU.

5. Nikishyna, O. V. (2019). Suchasni vektory innovatsiinoho rozvytku ta hlokalizatsii ahrarnoho rynku Odeskoi oblasti. Aktualni Problemy Suchasnoho Upravlinnia v Sotsialno-Ekonomichnykh, Humanitarnykh Ta Tekhnichnykh Systemakh, 10-24.

6. Kopylova, T. V. (Ed.). (2018). Statystychnyi shchorichnyk Odeskoi oblasti za 2017 rik. Odesa: Holovne upravlinnia statystyky v Odeskii oblasti.

7. Nikishyna, O. V., \& Bibikova, N. O. (2018). Rozvytok rehionalnykh obsluhovuiuchykh kooperatyviv zernovoho rynku: intehratsiinyi pidkhid. Odesa: IPREED NAN Ukrainy.

8. P'iat faktiv pro orhanichne zemlerobstvo v Ukraini. (2018). Retrieved August 12, 2019, from https://bakertilly.ua/news/id45259.

9. Marmul, L. O., \& Novak, N. P. (2016). Rozvytok orhanichnoho vyrobnytstva v Ukraini na zasadakh kooperatsii. Ekonomika APK, (9), 26-32.

10. Eksportna stratehiia («dorozhnia karta» stratehichnoho rozvytku torhivli) Ukrainy na 2017-2021 roky. (2017). Retrieved October 21, 2019, from http://zakon2.rada.gov.ua/laws/show/1017-2017-p.

11. Savenko, I. I., \& Sedikova, I. O. (2012). Orhanizatsiino-ekonomichnyi mekhanizm funktsionuvannia pidpryiemstv zernovoho pidkompleksu. Odesa: Polihraf.

12. Sedikova, I. O. (2013). Innovatsiini metody upravlinnia pidpryiemstvamy zernoproduktovoho pidkompleksu. Biznes Inform, (1), 114-117.

13. Lipov, V. V. (2018). Konkurentnaya strategiya Ukrainyi v usloviyah globalizatsii. Ekonomika Ukrainyi,

14. Rynok zerna Ukrainy: vid eksportu syrovyny do hotovoi produktsii. (2017). Retrieved October 20, 2019, from https://agronews.ua/node/82481.

Received 10 October2019

Approved 24 October 2019

Available in Internet 26.12.2019

Цитування згідно ДСТУ 8302:2015

Нікішина О.В. Сценарії та стратегічні напрями інноваційного розвитку регіонального ринку зерна й продуктів його переробки на засадах глокалізації // Економіка харчової промисловості. 2019. Т.11, вип. 4. С. 3-13. doi:10.15673/fie.v11i4.1540

Cite as APA style citation

Nikishyna, O. (2019). Scenarios and strategic directions of innovative development of the regional market of grain and products of its processing on the basis of glocalization. Food Industry Economics, 11(4), 3-13. doi:10.15673/fie.v11i4.1540 